\title{
Ethnologies
}

Changing Sounds: New Directions and Configurations in Popular Music. By Tony Mitchell and Peter Doyle with Bruce Johnson, editors. IASPM 1999 International Conference Proceedings, Faculty of Humanities and Social Sciences, University of Technology Sydney. (Sydney: University of Technology, 2000. 438 p., ISBN 1-86365-364-3).

\section{Michael Taft}

Volume 24, numéro 1, 2002

Espace

Space

URI : https://id.erudit.org/iderudit/006545ar

DOI : https://doi.org/10.7202/006545ar

Aller au sommaire du numéro

Éditeur(s)

Association Canadienne d'Ethnologie et de Folklore

ISSN

1481-5974 (imprimé)

1708-0401 (numérique)

Découvrir la revue

Citer ce compte rendu

Taft, M. (2002). Compte rendu de [Changing Sounds: New Directions and Configurations in Popular Music. By Tony Mitchell and Peter Doyle with Bruce Johnson, editors. IASPM 1999 International Conference Proceedings, Faculty of Humanities and Social Sciences, University of Technology Sydney. (Sydney: University of Technology, 2000. 438 p., ISBN 1-86365-364-3).]

Ethnologies, 24(1), 303-305. https://doi.org/10.7202/006545ar d'utilisation que vous pouvez consulter en ligne. 
The remaining two chapters discuss sport in relation to the "body" and in relation to "nation". The former is a well documented discussion of the politics of bodily representation as it relates to class and to gender. The latter presents the manner in which sport became a tool for expressing nationalistic will and political supremacy. The sections that consider Cold War politics and the struggle for sport dominance and Canada's ambivalence towards funding high performance sport/athletes are especially good.

Blood, Sweat, and Cheers is a historically sound text that is extremely accessible for general readership and for introductory courses in sport and Canadian history. The lack of critical development of certain issues may be disconcerting for certain readers, but they need only be directed to Kidd's The Struggle for Canadian Sport. In the end Howell achieves what he sets out do, which is create a book that "will encourage people to think of these [sport related] issues, and contribute to the ongoing debate about sport and the making of Canada" (146).

\section{Reference}

Kidd, Bruce. 1996. The Struggle for Canadian Sport. Toronto: University of Toronto Press.

Michael A. Robidoux The University of Lethbridge, Alberta

Changing Sounds: New Directions and Configurations in Popular Music. By Tony Mitchell and Peter Doyle with Bruce Johnson, editors. IASPM 1999 International Conference Proceedings, Faculty of Humanities and Social Sciences, University of Technology Sydney. (Sydney: University of Technology, 2000. 438 p., ISBN 1-86365-364-3).

This proceedings of the International Association for the Study of Popular Music contains 79 articles, as well as an introduction by Tony Mitchell and closing remarks by Will Straw. Any attempt to review all of the articles, spanning as they do popular musics of many varieties and many places, is impossible in a short essay. Rather, I will concentrate on those studies that relate in some way to Canadian popular music, before attempting an overview of how this publication reflects current trends in popular music scholarship. 
All of the Canadian studies analyze quite specific aspects of popular music, and do not lead to any general conclusions about the nature of the Canadian music. Peter Narváez's study (150-56) of notions of authenticity, political meaning, aesthetics, and pragmatics as found in the history of acoustic vs. electric guitars is a revealing document that should lead to more treatments of the intersection of material history with popular music. His study-examples are Canadian blues singers, but he could as well have taken musicians from other countries. The other Canadian studies deal with aspects of Quebec popular music. Val Morrison's exploration (102-05) of the Innu/Montagnais group, Kashtin, shows the ambivalent reception of this band within the "cultural citizenry" of Quebec, especially in the context of the Oka crisis, and is a fine analysis of the political dimensions of authenticity. Roger Chamberland (120-23) offers an ethnography of the neopunk scene in Quebec, making use of participant observation to discover shared rules of concert behaviour, shared feelings of alienation from the adult world, as well as the shared aesthetic of lyrics, dance, and style.

Geoff Stahl (290-94) looks at the Montreal independent label, Derivative, in his exploration of what constitutes a "scene" in rock music; his conclusion that "scene" is partly allied to geography, but more especially the result of a cross-border constituency of aficionados is an evenhanded approach to the topic. Mark Evans's examination (25255) of two CDs by singer Alanis Morissette holds little interest for folklorists, being a literary/cultural studies analysis of her "grain" of voice (a Barthesian concept).

Quebec's other female pop star, Céline Dion, undergoes a more interesting analysis by Line Grenier (263-66), who shows that seeing Dion's success as nothing more than a product of the music industry's commercial strategies ignores several important factors in the creation of celebrity, especially the ambivalent forces related to nationalism and globalism that give a more complete picture of what makes an international pop star.

Will Straw's analysis of the political economy of credibility in popular music (260-62) uses Canadian examples, but is really about the larger issue of the decline in popularity of Anglo-American popular music around the world, in favour of crossover and imitative local musics. He shows that, in the interplay between local and global, the seeming "credibility" of Anglo-American music makes it appear insular to the 
rest of the world, while local imitative traditions allow a shared aesthetic of appropriation that many around the world can more easily relate to.

Straw's analysis is, in fact, indicative of the general thrust of the proceedings: the local/global tensions that help shape popularity in music. Tony Mitchell's introduction applauds the celebration of the "local" during the conference, and notes that the papers concentrated to a great extent on alternative musics outside of the United States and the United Kingdom. Steven Feld's "Anxiety and Celebration: Mapping the Discourses of "World Music"' (9-14) speaks most forcibly to local/ global tensions, commodification and homogenization, hybridity, and resistance - all factors that explain the current state of popular music.

What is less apparent in these studies is the ethnographic approach to popularity. What are people listening to, and how are they "using" music? In almost all cases, these papers start from the point of view of a specific kind of music, a performer or group of performers, or a particular phenomenon in popular music. There are fewer examinations that begin within a community of listeners. Even those scholars who do examine communities look for examples of kinds of popular music, rather than assessing a group's notion of popularity itself. Where are the studies of music in the home, school concert traditions, or music in the workplace? Reading all of the articles in this book will give some clues about these issues, but only in a tangential way.

In searching for "what is popularity", the IASPM tends to look at rock music, "world music", the international music industry, as well as traditions of limited popularity (e.g., non-US singing cowboy music). There is something of interest in all of these topics? they are all legitimate. Yet there are still vast areas of popularity that seem outside the scope of these scholars, even though they are in the forefront of popular music for anyone who cares to look. Where are the studies of Liberace, Victor Borge, the Three Tenors and other popular classical music traditions? Holly Everett's study of a classical music radio station in Austin (26771 ) is the only representative in this book. When will we have a body of scholarship that looks at international phenomena such as Nana Mouskouri, Roger Whittaker, or Julio Iglesias? There is much work yet to be done. 